\title{
Oxidative coupling-thionation of amines mediated by iron-based imidazolium salts for the preparation of thioamides
}

\author{
Patricia Gisbert \\ Isidro M. Pastor* \\ ${ }^{a}$ Organic Chemistry Department and Instituto de Síntesis Orgánica (ISO), University of Alicante, Apdo. 99, 03080 Alicante, Spain \\ ipastor@ua.es
}

\begin{abstract}
An efficient and selective multicomponent oxidative coupling, involving the use of two different amines, sodium phosphate and elemental sulfur have been described for the preparation of thioamides, employing microwave irradiation. The use of an iron(III)-based imidazolium salt resulted essential as catalyst. Indeed, the iron based catalyst is involved in the oxidative coupling of the two amines and in the subsequent C-S bond formation. The protocol is useful for a wide variety of primary benzylamines and alkylamines, as coupling partners. Thus, various electron-rich and electron-poor substituents in the aromatic rings and also fused piperidine derivative, are suitable starting materials in this reaction, being some of obtained products important synthetic intermediates of natural products findings.
\end{abstract}

Key words imidazolium salt, ionic liquid, iron(III) catalyst, sulfur, thioamides

Compounds bearing thioamide moieties constitute one of the most attractive families of sulfur-containing molecules. ${ }^{1}$ They are notably valuable building blocks for the preparation of biologically active compounds (e.g. duloxetine), ${ }^{2}$ including bioactive heterocycles ${ }^{3}$ and natural products, such as Caprazamycin B. ${ }^{4}$ The presence of a thioamide moiety in natural products is occasional, albeit most of these thioamidecontaining compounds present interesting bioactivity. ${ }^{5}$ Moreover, different bioactive oxoamides have been converted into the corresponding thioamides for structure-activity relationship studies and biological activity assessment, being thioamide containing proteins of special interest. ${ }^{6}$

There are several approaches, in the literature, to the synthesis of compounds containing thioamide moieties, ${ }^{7}$ including protocols to prepare thioamides using different sulfur reagents in the presence of aerobic oxidation. ${ }^{8}$ Among them, the most employed methodologies have been the thioacylation of amines and the thionation of amides using sulfur reagents, such as $\mathrm{P}_{4} \mathrm{~S}_{10}{ }^{9}$ or the Lawesson's reagent. ${ }^{10}$ However, the $0 / \mathrm{S}$ exchange with these sulfur reagents cannot be classified as an atom economy approach. In this sense, Kindler reported a multicomponent reaction of a carbonyl compound, an amine and elemental sulfur (Scheme 1a), representing a transformation with a good atom economy evaluation. ${ }^{11}$ More recently, Nguyen et al. described a three-component reaction involving sulfur and amines to give the corresponding thioamides following the general reaction depicted in Scheme 1b. ${ }^{12}$ However, both procedures present two main limitations, the need of high temperatures and long reaction times. In order to reduce the reaction time, we considered the use of microwave heating as a useful approach. ${ }^{13}$ In this sense, to the best of our knowledge, there are only two reported protocols for the preparation of thioamides using elemental sulfur in which microwave irradiation is employed. The reported procedure by the group of Keglevich allowed only the thionation of the benzylic position starting from the corresponding benzylamines. ${ }^{14}$ On the other hand, the work by Kappe described the coupling between aldehydes and amines to form the corresponding thioamides in the presence of sulfur. ${ }^{15}$

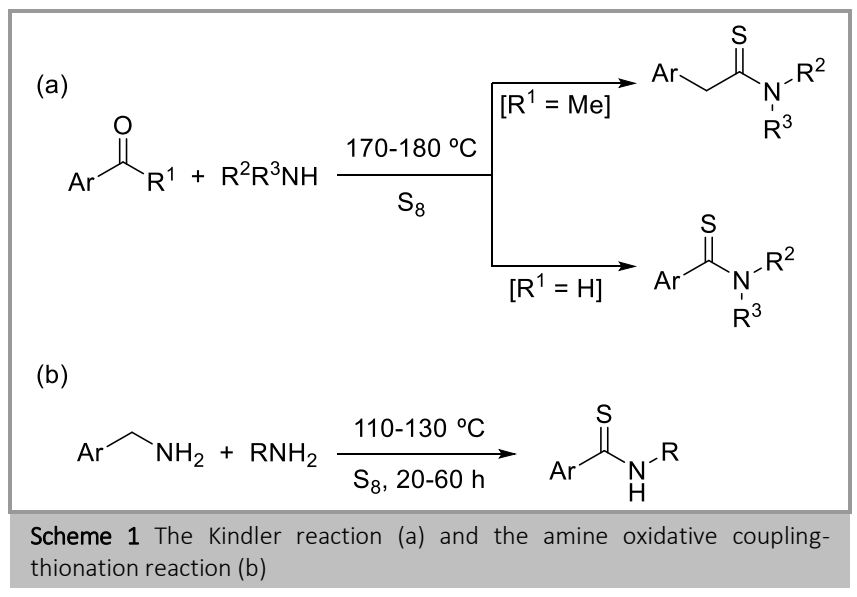

Aware of the importance of finding sustainable processes, we consider of special significance the search for sustainable catalytic systems, both heterogeneous and homogeneous, which allow their profitability with the least impact on the environment. In this context, we have focused our attention on the use of functionalized imidazoles as versatile components for catalytic systems in combination with different metals. Indeed, we have employed acyl-functionalized imidazole derivatives as precursors for N-heterocyclic carbene (NHC) ligands for palladium. ${ }^{16}$ Furthermore, we have also described the use of 1,3bis(carboxymethyl)imidazole (bcmim) as ligand in the preparation of metal-organic frameworks (MOFs), which have been employed as effective heterogeneous catalysts. Indeed, the obtained material in combination with copper ( $\mathrm{Cu}$-bcmim) has efficiently catalyzed the oxidative coupling between carboxylic acids and formamides. ${ }^{17}$ Moreover, the barium- and calciumorganic frameworks (Ba-bcmim and Ca-bcmim) have been revealed as a variety of complementary catalysts for the Friedländer reaction. ${ }^{18}$ 


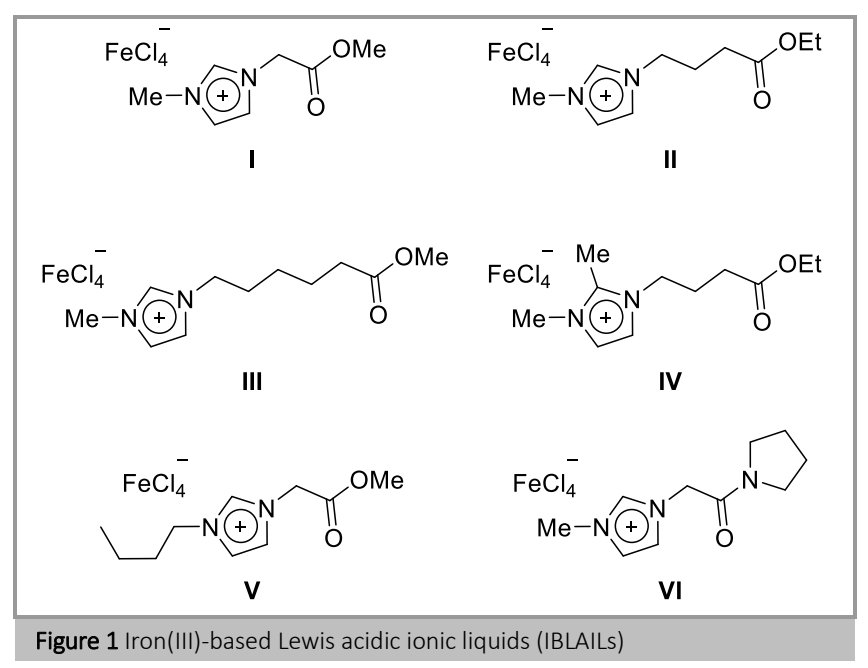

As a part of this research, we have used acyl-imidazolium derivatives for the preparation of iron(III)-based Lewis acidic ionic liquids (IBLAILs, Figure 1), which have been employed as catalysts in the selective preparation of quinolines, 2allylanilines and 4-allylanilines by modulating the reaction conditions. ${ }^{19}$ This type of metal-ion-containing ionic liquids ${ }^{20}$ are easily prepared, being environmentally friendly catalytic systems. Moreover, iron in combination with sulfur is able to form iron-sulfur clusters ${ }^{21}$ responsible for a variety of chemical transformations due to their ubiquity in living systems and responsible for a wide range of chemical transformations as fundamentals in life processes. Consequently, we posit a sustainable amine oxidative coupling-thionation reaction employing IBLAILs as potential efficient catalytic systems. Herein, we are pleased to report our findings in a new synthetic approach using microwave irradiation to thioamides via iminemediated selective thionation under aerobic conditions.

Initial efforts were focused on the optimization of the reaction conditions using benzylamine (1a) and elemental sulfur as model reactants. Firstly, the reaction was carried out with 15 mol-\% of Fe(III)-based Lewis acidic ionic liquid I (Figure 1) as catalyst at $100{ }^{\circ} \mathrm{C}$ under solvent-free conditions, obtaining the desired thioamide 2a in $43 \%$ yield (Table 1, entry 1). Different substituents in the imidazole moieties can modulate the catalytic activity of the salts due to the fact that the properties of ionic liquids can be different depending on the size of the components. ${ }^{22}$ Moreover, the presence of a functional group, such as acyl moieties, could help during the catalytic process. ${ }^{19}$ Consequently, a variety of Fe(III)-based Lewis acidic ionic liquids, such as I-VI (Figure 1), were evaluated as catalysts in the oxidative coupling-thionation reaction of benzylamine (1a). The reactions were performed with 15 mol-\% of IBLAIL (I-VI) under the starting conditions (Table 1, entries 1-6). While catalysts II, IV, $\mathbf{V}$ and VI provided lower yields (Table 1, entries 2, 4, 5 and 6), catalysts I and III proved to be superior at that temperature (Table 1, entries 1 and 3). In an attempt to improve the thioamide formation, we evaluated different bases (Table 1, entries 8-10), not observing any significant improvement. In addition, the absence of a base resulted in a poor conversion to the final product (Table 1, entry 7), proving the need of a base. Next, we studied the effect of the temperature in the range 60$100{ }^{\circ} \mathrm{C}$. The reaction carried out at $100{ }^{\circ} \mathrm{C}$ gave the best conversion to the coupling-thionation product, observing lower conversion to the desired product at lower temperatures (Table 1 , entries 11 and 12). We also proved that the catalyst was active when the reaction was performed using conventional heating $\left(100^{\circ} \mathrm{C}\right.$, Table 1 , entry 13$)$, although the product was obtained with lower yield. The product was observed in a much reduced conversion when the reaction was carried out in the absence of catalyst, compared to our optimal conditions (Table 1, compare entries 3 and 14). Thus, the iron(III) catalyst is important for the reaction, being the combination of a strong base and sulfur not enough. ${ }^{23}$ Furthermore, different solvents, such as toluene, 1,4dioxane or 1,2-dichloroethane, were evaluated, providing, in all the cases, lower yields than under 'neat' reaction conditions.

\begin{tabular}{|c|c|c|c|c|}
\hline \multicolumn{2}{|c|}{$1 a$} & \multicolumn{2}{|c|}{$\begin{array}{c}\text { IBLAIL }(15 \mathrm{~mol}-\%) \\
\text { neat } \\
\mathrm{T}\left({ }^{\circ} \mathrm{C}\right) \text {, base }\end{array}$} & $2 a$ \\
\hline Entry & IBLAIL & Base & $\mathrm{T}\left({ }^{\circ} \mathrm{C}\right)$ & Yield $(\%)^{b}$ \\
\hline 1 & 1 & $\mathrm{Na}_{3} \mathrm{PO}_{4}$ & 100 & 43 \\
\hline 2 & $\|$ & $\mathrm{Na}_{3} \mathrm{PO}_{4}$ & 100 & 30 \\
\hline 3 & III & $\mathrm{Na}_{3} \mathrm{PO}_{4}$ & 100 & 49 \\
\hline 4 & IV & $\mathrm{Na}_{3} \mathrm{PO}_{4}$ & 100 & 34 \\
\hline 5 & $\mathrm{~V}$ & $\mathrm{Na}_{3} \mathrm{PO}_{4}$ & 100 & 39 \\
\hline 6 & $\mathrm{VI}$ & $\mathrm{Na}_{3} \mathrm{PO}_{4}$ & 100 & 39 \\
\hline 7 & III & No base & 100 & 6 \\
\hline 8 & III & $\mathrm{Na}_{2} \mathrm{CO}_{3}$ & 100 & 37 \\
\hline 9 & III & $\mathrm{Et}_{3} \mathrm{~N}$ & 100 & 39 \\
\hline 10 & III & $\mathrm{K}_{3} \mathrm{PO}_{4}$ & 100 & 30 \\
\hline 11 & III & $\mathrm{Na}_{3} \mathrm{PO}_{4}$ & 60 & 25 \\
\hline 12 & III & $\mathrm{Na}_{3} \mathrm{PO}_{4}$ & 80 & 28 \\
\hline $13^{c}$ & III & $\mathrm{Na}_{3} \mathrm{PO}_{4}$ & 100 & 34 \\
\hline 14 & No catalyst & $\mathrm{Na}_{3} \mathrm{PO}_{4}$ & 100 & 21 \\
\hline
\end{tabular}

a Reaction conditions: $1 \mathrm{a}(1 \mathrm{mmol}), \mathrm{S}(0.5 \mathrm{mmol})$, base $(0.5 \mathrm{mmol})$, catalyst (15 mol-\%), microwave heating ( $80 \mathrm{~W}), 1 \mathrm{~h}$.

b Yield determined by GC using 4,4'-di-tert-butylbiphenyl (DTBB) as internal standard.

${ }^{c}$ Conventional heating $(24 \mathrm{~h})$ using an oil bath was employed.

Next, we turned our attention to the amounts of base and sulfur. Thus, different quantities (i.e. $0.5,1$ and $1.5 \mathrm{mmol}$ ) of sodium phosphate and elemental sulfur were employed, and the results are depicted in the graph (Figure 2). Interestingly, an interaction could be observed between the amount of sodium phosphate and elemental sulfur. Indeed, there is a dependence of the conversion on the amount of both reagents used (Figure 2). However, the profile obtained for the three distributions is dissimilar. Different conclusions can be drawn from this study: (i) small amounts of base and elemental sulfur do not show interaction (Figure 2); (ii) up to a certain amount of base $(0.5$ $\mathrm{mmol}$ ), the amount of sulfur is central, being $1.5 \mathrm{mmol}$ of sulfur the optimum (Figure 2); (iii) a minor decreasing in yield occurs when the number of equivalents of base is superior to an optimum value (Figure 2). Gratifyingly, $89 \%$ of conversion to the desired product 2a was observed when the reaction was performed employing the optimal amount of base and sulfur at $100^{\circ} \mathrm{C}$ for $1 \mathrm{~h}$ under solvent-free conditions, using IBLAIL III as catalyst (Figure 2). At this point, we performed a reaction employing $\mathrm{FeCl}_{3}$ as catalyst instead of the IBLAIL III, giving only $35 \%$ conversion to the desired product. This experiment proved that not only iron(III) is important in the result of the 
reaction, but also the structure of the functionalized imidazolium ion.

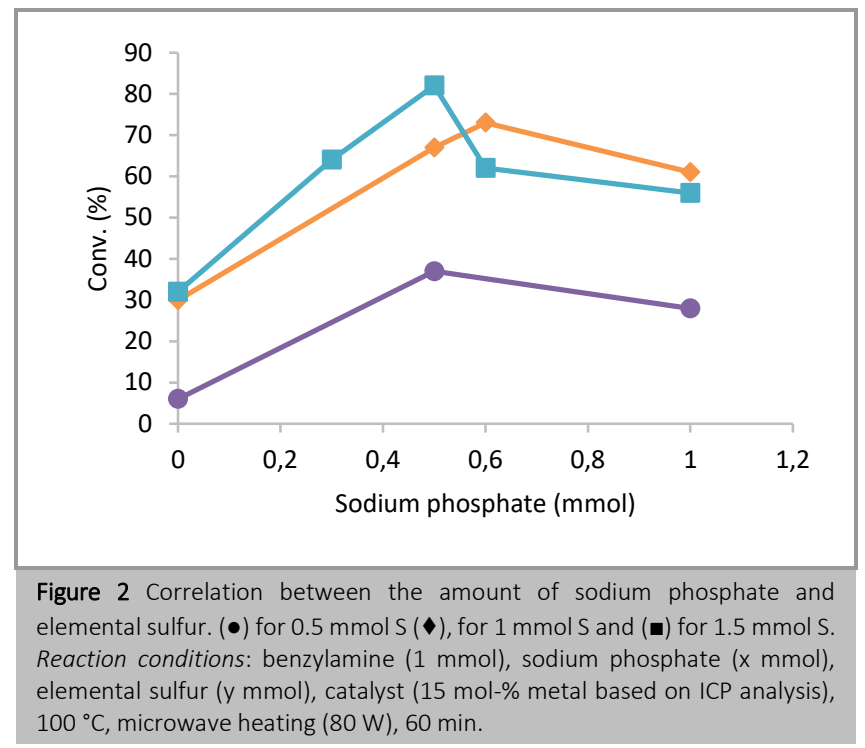

With the optimized reaction conditions for the thionationcoupling of benzamines in hand, we examined the scope of the present reaction with different benzamines 1 (Scheme 2). As mentioned before, benzylamine (1a) was transformed into the corresponding thioamide (89\% conversion) with excellent isolated yield (87\%). Aromatic rings bearing electron-donating and electron-withdrawing groups were subjected to this procedure and generated the corresponding products from moderate to good yields ( $\mathbf{2} \mathbf{b}, \mathbf{2 d}, \mathbf{2 e}, \mathbf{2} \mathbf{h}, \mathbf{2 i})$. In this context, the more withdrawing ability of the group, the poorest the yield in the final product (Scheme 2). However, the presence of two methoxy groups in the benzylamine (i.e. 3,4dimethoxyphenylmethylamine) resulted in the formation of the corresponding product in poor yield $(<20 \%)$, under these conditions. The presence of two methoxy groups aromatic amines has previously shown lower activity, in other transformations, in the presence of IBLAILs. ${ }^{19}$ Interestingly, 1phenylethanamine 1f was also employed, leading to the formation of the phenylthioacetamide $\mathbf{2} \mathbf{f}$ in moderate yield. In this case, the transformation involves a Willgerodt rearrangement (see Supporting Information). ${ }^{24}$ In a like manner, 2-phenylethanamine produced the thioamide 2c in moderate yield.

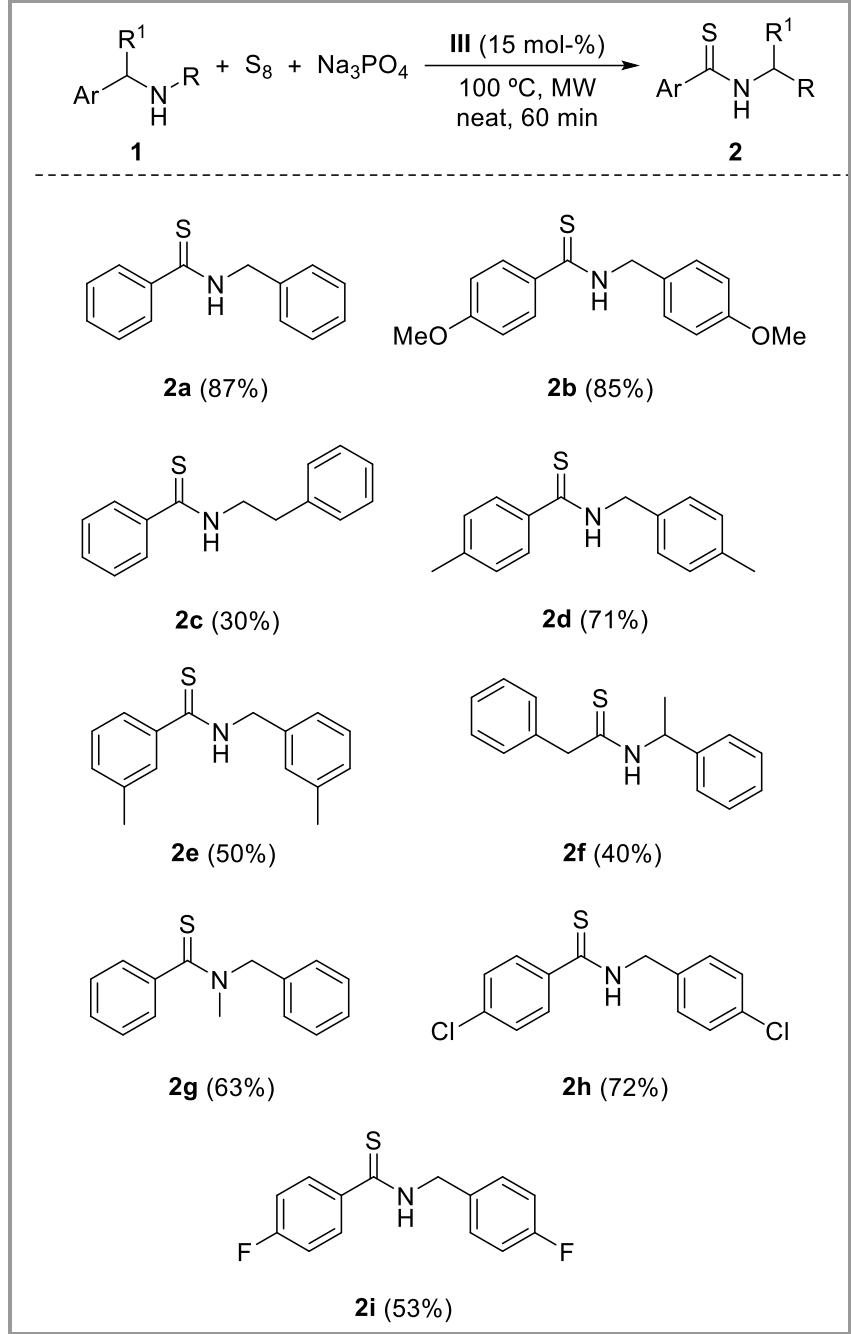

Scheme 2 Scope evaluation of homocoupling-thionation reaction. Reaction conditions: 1 ( $2 \mathrm{mmol}), \mathrm{S}(1.5 \mathrm{mmol}), \mathrm{Na}_{3} \mathrm{PO}_{4}(1 \mathrm{mmol})$, III $(15 \mathrm{~mol}-\%)$, microwave heating $(80 \mathrm{~W})$. In parentheses: isolated yield after flash chromatography or preparative TLC.

To broaden the scope to other amines, we carried out the reaction under the same conditions employing secondary and tertiary amines. The reaction of $N$-methylbenzylamine $1 \mathrm{~g}$ with sulfur yielded a mixture of $N$-methylthiobenzamide (3) and $N$ benzyl- $N$-methyl-thiobenzamide (2g) in 1:1 ratio (Scheme 3). Then, we decided to modulate the reaction conditions in order to increase the selectivity of the process. First, the reaction was tested at different temperatures $\left(80\right.$ and $\left.120^{\circ} \mathrm{C}\right)$ without any change in the selectivity. Aware of the influence of the sulfur amount in the outcome of the reaction, as we observed above, we conducted different experiments modulating the amount of sulfur in the model reaction. Interestingly, only product $\mathbf{2 g}$ was isolated in $63 \%$ yield when the reaction was performed with less amount of sulfur (Schemes 2 and 3). On the contrary, increasing the amount of sulfur the reaction produced exclusively the thionation compound $\mathbf{3}$, which was isolated in 87\% yield (Schemes 3 and 4). Moreover, with tertiary amines, such as $N, N$-dimethylbenzylamine, we did not observe any product neither by thionation nor by oxidative couplingthionation, recovering the starting materials after the reaction. 


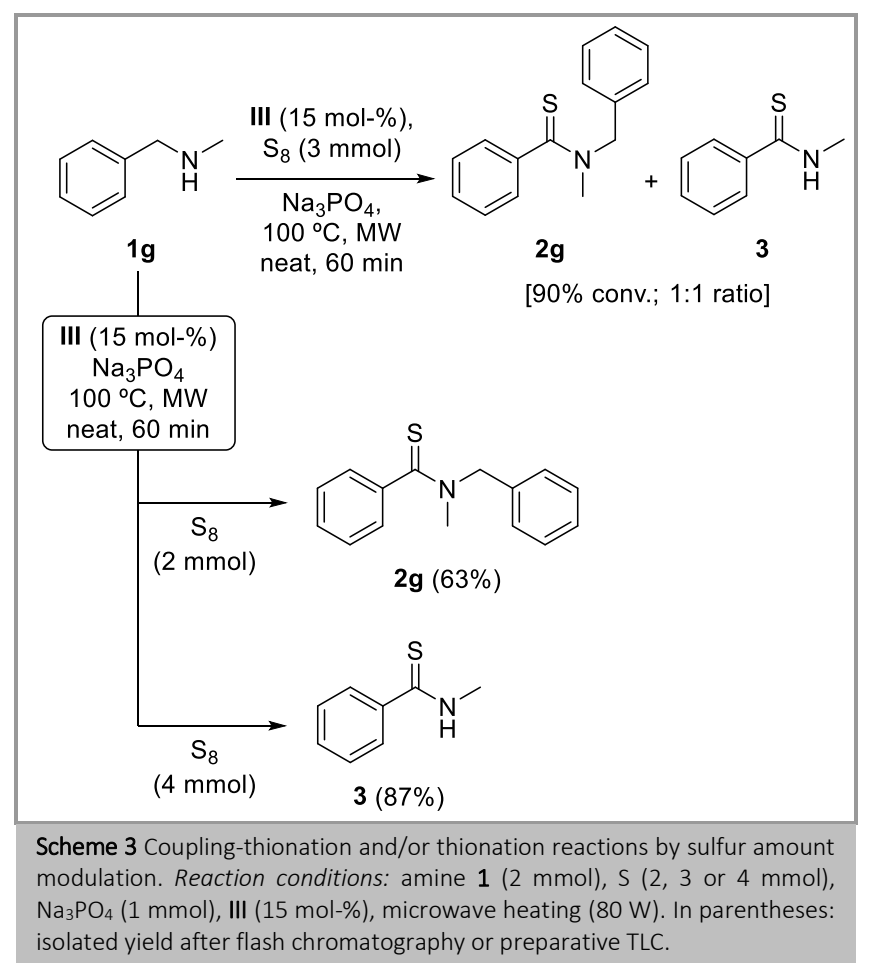

We next attempted the thionation at the benzylic position of different arylmethylamine derivatives, such as $\mathrm{N}$ methylbenzylamine, dibenzylamine and fused piperidine derivative 1,2,3,4-tetrahydroisoquinoline. As expected, compounds $\mathbf{2 a}, \mathbf{3}$ and $\mathbf{4}$ were exclusively obtained (Scheme 4) without any by-product carrying out the thionation reaction with elemental sulfur. This is in sharp contrast with previously reported protocols in the literature, which produced a mixture of different sulfur-containing compounds. ${ }^{14}$

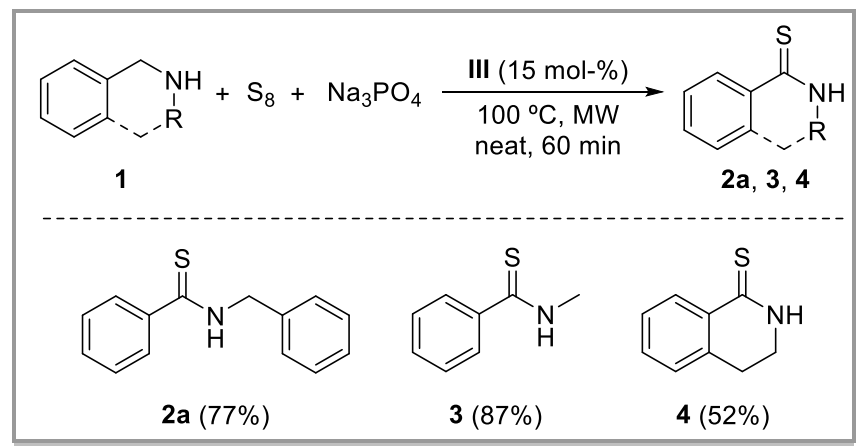

Scheme 4 Thionation of benzylic position. Reaction conditions: amine (2 $\mathrm{mmol}$ ), S (4 mmol), $\mathrm{Na}_{3} \mathrm{PO}_{4}(1 \mathrm{mmol})$, III (15 mol-\%), microwave heating (80 $W)$. In parentheses: isolated yield after flash chromatography.

The oxidative coupling of two different amines using elemental sulfur can afford, in principle, four possible thioamides (Figure $3)$. For this reason, we decided to explore the selectivity of our catalytic system in the oxidative coupling-thionation reaction of two amines. To address this question, we set up a model reaction of $\mathrm{N}$-methylbenzylamine and morpholine in the presence of elemental sulfur employing the optimal conditions for the homocoupling-thionation. Firstly, we decided to use an equimolar mixture of the two amines, and the heterocouplingthionation product was obtained in $26 \%$ conversion, being the rest of the $N$-methylbenzylamine transformed into the homocoupling-thionation product $\mathbf{2 g}$. Next, we decided to add an additional quantity of morpholine (1.3 equiv.) in order to favor the conversion to the expected cross-coupled product $\mathbf{2 j}$, which was obtained in $67 \%$ conversion. Increasing the reaction time to 90 minutes resulted in comparable conversion (61\%). Augmenting the amount of base (up to 2 equiv.) resulted in an improvement in the formation of the expected thiomide, being obtained compound $\mathbf{2} \mathbf{j}$ with a conversion of $80 \%$. The product $\mathbf{2 j}$ was easily isolated in $73 \%$ yield (Table 2 , entry 1 ) from the reaction mixture. In subsequent studies, we applied these reaction conditions to investigate the generality of this procedure and demonstrate the applicability of the synthetic method (Table 2). In all the tested cases, the corresponding heterocoupled thioamides $\mathbf{2}$ were obtained in moderate to good yields. Indeed, the reaction between morpholine and 4chlorophenylmethanamide gave the corresponding thioamide $\mathbf{2 k}$ with $73 \%$ yield. Likewise, another secondary amine, such as pyrrolidine, coupled with $N$-methylbenzylamine giving the thioamide 21 (Table 2). Simple aliphatic primary amines, such as $n$-octylamine, gave also selectively the coupling with benzylamine and 4-methoxyphenylmethanamine giving the corresponding thioamides $\mathbf{2 m}$ and $\mathbf{2 n}$ in good yields $(82 \%$ and $76 \%$, respectively, Table 2). Moreover, 2-phenylethanamine was reacted with $N$-methylbenzylamine yielding the product 2c in $61 \%$, being a better result than the one obtained when the homocoupling thionation of 2-phenylethanamine was performed (Scheme 2). Other functionalized benzylamines with electron-donating and electron-withdrawing groups were coupled with 2-phenylethanamine affording the corresponding thioamides 2o, 2p and 2q in moderate to good yields (Table 2).

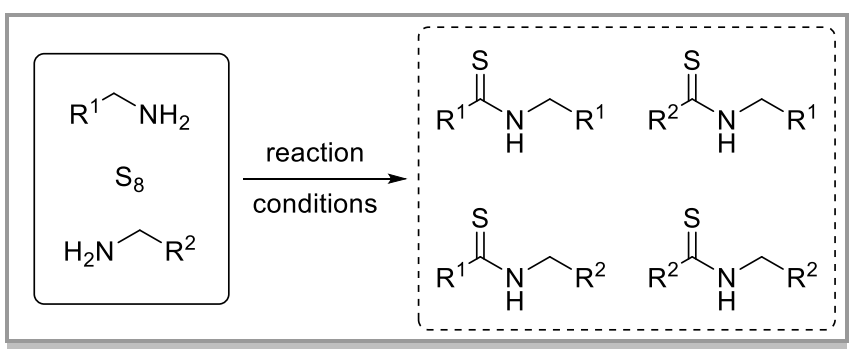

Figure 3 Oxidative coupling-thionation of two amines

As commented previously, our research group has observed an oxidative step during the preparation of quinolines by cyclization of the corresponding 2-allylanilines using atmospheric oxygen in the presence of IBLAILs. ${ }^{19}$ Based on that, we considered that our catalytic system could favor the imine formation via oxidation of the corresponding benzylamine. In order to gain mechanistic insight into the reaction proceeding via imine reaction intermediates, we carried out the reaction of benzylamine in the presence of IBLAIL III, in the absence of elemental sulfur and base. Interestingly, the predicted benzaldimine $\mathbf{5}$ was formed in $70 \%$ yield after 30 minutes (Scheme 5), proving the importance of the atmospheric oxygen in the presence of our catalyst during the oxidation process. Furthermore, we proved that the expected thioamide 2a was obtained, in $80 \%$ yield, when the imine $\mathbf{5}$ was treated under the standard reaction conditions. 
Table 2 Scope evaluation of coupling-thionation reaction of two amines ${ }^{a}$

\begin{tabular}{|c|c|c|c|c|c|c|}
\hline $\mathrm{Ar}^{-}$ & $\mathrm{R}^{1}+\mathrm{R}^{2}$ & $\begin{array}{c}\text { III }(15 \mathrm{~mol}-\%) \\
\mathrm{S}_{8}, \mathrm{Na}_{3} \mathrm{PO}_{4} \\
100^{\circ} \mathrm{C}, \mathrm{MW} \\
\text { neat, } 60 \mathrm{~min}\end{array}$ & $\begin{array}{c}\mathrm{Ar}_{N^{\prime}} \mathrm{N}^{-R^{3}} \\
\mathrm{R}^{2} \\
\mathbf{2 c}, \mathbf{2 j - 2 q}\end{array}$ & & & \\
\hline Entry & $\mathrm{ArCH}_{2} \mathrm{NHR}^{1}$ & & $\mathrm{R}^{2} \mathrm{R}^{3} \mathrm{NH}$ & Thioamide & no. & Yield $(\%)^{b}$ \\
\hline $1^{c}$ & & & $\mathrm{HN}^{\widehat{N}}$ & & $2 j$ & 73 \\
\hline $2^{c}$ & & $\mathrm{IH}_{2}$ & $\mathrm{HN}^{\prime}$ & & $2 k$ & 73 \\
\hline $3^{c}$ & & & $\mathrm{HN}^{-}$ & & 21 & 42 \\
\hline 4 & & & $\mathrm{H}_{2} \mathrm{~N} \Upsilon \gamma_{6}$ & & $2 m$ & 82 \\
\hline 5 & & $\mathrm{NH}_{2}$ & $\mathrm{H}_{2} \mathrm{~N} \Upsilon \gamma_{6}$ & & $2 n$ & 76 \\
\hline 6 & & & & & $2 c$ & 61 \\
\hline 7 & & $\mathrm{NH}_{2}$ & & & 20 & 61 \\
\hline 8 & & $\mathrm{H}_{2}$ & & & $2 p$ & 54 \\
\hline 9 & & $\mathrm{H}_{2}$ & & & $2 q$ & 41 \\
\hline
\end{tabular}

a Reaction conditions: $\operatorname{ArCH}_{2} \mathrm{NHR}^{1}(1 \mathrm{mmol}), \mathrm{R}^{2} \mathrm{R}^{3} \mathrm{NH}$ (1.3 mmol), S (3 mmol), $\mathrm{Na}_{3} \mathrm{PO}_{4}(1 \mathrm{mmol}), \mathrm{III}$ (15 mol-\%), microwave heating (80 W), $1 \mathrm{~h}$.

${ }^{b}$ In parentheses: isolated yield of pure product after flash chromatography or preparative TLC.

c Reaction performed with $2 \mathrm{mmol}$ of $\mathrm{Na}_{3} \mathrm{PO}_{4}$.

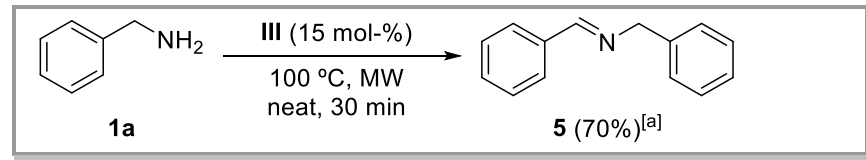

Scheme 5 Oxidative coupling of benzylamine. [a] Yield determined by GC using $4,4^{\prime}$-di-tert-butylbiphenyl (DTBB) as internal standard.

Based on these observations and on similar transformations previously reported, ${ }^{12 a}$ we tentatively proposed a mechanism for the oxidative coupling-thionation reaction of two amines as represented in Scheme 6. The first step (a) of the reaction could be the oxidation of $\mathbf{1}$ into benzaldimine $\mathbf{A}$, being the oxidation mediated by the iron catalyst as described beforehand. ${ }^{19}$ However, the oxidation can be driven by elemental sulfur itself or by iron-sulfur clusters, as we mentioned above. Next, imine $\mathbf{A}$ could follow two different pathways: (i) thionation by elemental sulfur, in which imine $\mathbf{A}$ is transformed directly into thiobenzamides $\mathbf{2 a}, \mathbf{3}$ and $\mathbf{4}$ ( $\operatorname{step} \boldsymbol{b}$ ); (ii) reaction of imine $\mathbf{A}$ with a second amine molecule to provide intermediate B (step $\boldsymbol{c}$ ), followed by an elimination (step $\boldsymbol{d}$ ) catalyzed by IBLAIL. Finally, imine $\mathbf{C}$ reacts with sulfur affording the desired thioamide (step $\boldsymbol{e}$. 


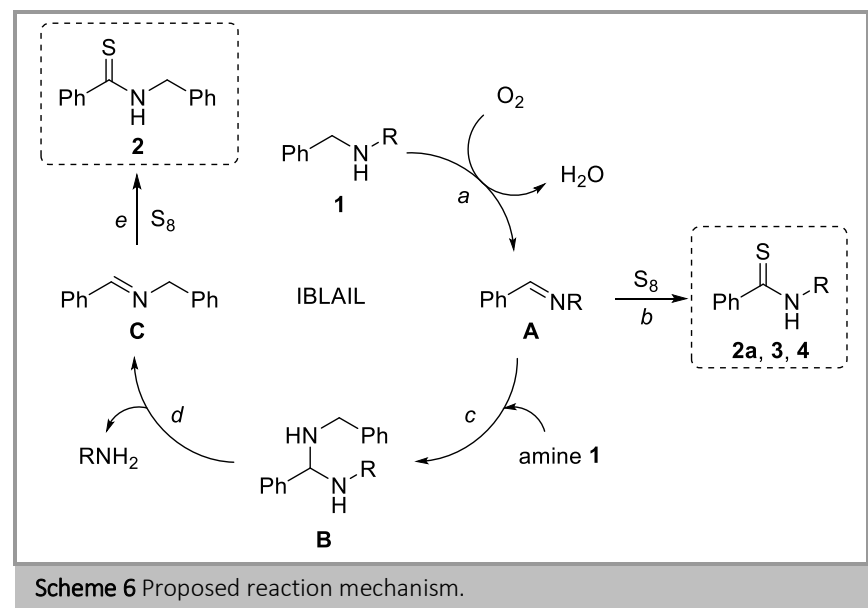

To conclude, we have demonstrated the efficacy of our catalytic system in a simple but effective and green synthesis of thioamides under iron-catalyzed aerobic conditions and microwave irradiation. A relevant feature of this type of iron(III) based catalytic systems is their easy and straightforward preparation. The synthesis of thioamines, in one-pot reaction, involves an oxidative process promoted by the studied catalytic system in the presence of atmospheric oxygen. The reported protocol allows the prepartion of thioamides in reasonable yields, even starting from two different amines. The different reactivity of amines was taken into consideration to minimize the homocoupling thionation reaction. It is likely that the catalytic activity of the mixture $\mathrm{Fe}$ /imidazolium salt may be applied to other transformations, whether in the presence of sulfur or not.

All reagents and solvents were used as supplied commercially. Analytical thin-layer chromatography (TLC) was performed on $0.2 \mathrm{~mm}$ coated Science silica gel (EM 60-F254) plates purchased from Merck, Germany. Visualization was achieved by UV light $(254 \mathrm{~nm})$. Flash column chromatography was performed using silica gel and a gradient solvent system (hexane-ethyl acetate as eluent). $1 \mathrm{H}$ and 13C NMR spectra were measured on 300 and $400 \mathrm{MHz}$ spectrometers and the residual solvent peak was used as an internal reference: proton (chloroform $\delta=7.26 \mathrm{ppm}$ ) and carbon (chloroform $\delta=77.16 \mathrm{ppm}$ ). Chemical shifts (ppm) were recorded with tetramethylsilane (TMS) as the internal reference standard. Multiplicities are given as s (singlet), brs (broad singlet), d (doublet), $\mathrm{t}$ (triplet), dd (doublet of doublets) or $\mathrm{m}$ (multiplet). The number of protons (n) for a given resonance is indicated by $\mathrm{nH}$ and coupling constants are reported as J values in $\mathrm{Hz}$. The conversions of the reactions and purity of the products were determinate by GC analysis using a Younglin $6100 \mathrm{GC}$, equipped with a flame ionization detector and a Phenomenex ZB-5 MS column (5\% PH-ME siloxane): 30 m (length), 0.25 $\mathrm{mm}$ (inner diameter) and $0.25 \mu \mathrm{m}$.

Homocoupling-thionation reaction in the thioamides synthesis; General procedure $A$

A mixture of amine (2 mmol), elemental sulfur (2, 3 or $4 \mathrm{mmol}), \mathrm{Na}_{3} \mathrm{PO}_{4}$ (1 mmol) and IBLAIL III (15 mol-\%) was heated under microwave irradiation (initial power $80 \mathrm{~W}$ ) for $1 \mathrm{~h}$. After completion of the reaction, the crude mixture was stirred vigorously with $\mathrm{CH}_{2} \mathrm{Cl}_{2}(5 \mathrm{~mL})$ and $\mathrm{MeOH}$ ( $1 \mathrm{~mL}$ ), and then filtered. Other portions of $\mathrm{CH}_{2} \mathrm{Cl}_{2}$ could be used to remove thoroughly all the $\mathrm{CH}_{2} \mathrm{Cl}_{2}$ soluble materials from the solid residue. The solvent was removed under vacuum, and the residue was purified by flash silica gel column chromatography using hexane-ethyl acetate or hexane-TBME as eluent.
Oxidative coupling-thionation reaction of two amines; General procedure B

A mixture of both amines [in ratio $1 \mathrm{mmol}\left(\mathrm{ArCH}_{2} \mathrm{NHR}^{1}\right)$ to $1.3 \mathrm{mmol}$ $\left(\mathrm{R}^{2} \mathrm{R}^{3} \mathrm{NH}\right)$ ], elemental sulfur ( $\left.3 \mathrm{mmol}\right), \mathrm{Na}_{3} \mathrm{PO}_{4}(1$ or $2 \mathrm{mmol}$ ) and IBLAIL III (15 mol-\%) was heated under microwave irradiation (initial power 80 W) for $1 \mathrm{~h}$. After completion of the reaction, the crude mixture was stirred vigorously with $\mathrm{CH}_{2} \mathrm{Cl}_{2}(5 \mathrm{~mL})$ and $\mathrm{MeOH}(1 \mathrm{~mL})$, and then filtered. Other portions of $\mathrm{CH}_{2} \mathrm{Cl}_{2}$ could be used to remove thoroughly all the $\mathrm{CH}_{2} \mathrm{Cl}_{2}$ soluble materials from the solid residue. The solvent was removed under vacuum, and the residue was purified by flash silica gel column chromatography using hexane-ethyl acetate or hexane-TBME as eluent.

\section{Thionation of benzylic position; General procedure C}

A mixture of amine ( $2 \mathrm{mmol}$ ), elemental sulfur ( $4 \mathrm{mmol}), \mathrm{Na}_{3} \mathrm{PO}_{4}(1 \mathrm{mmol})$ and IBLAIL III (15 mol-\%) was heated under microwave irradiation (initial power $80 \mathrm{~W}$ ) for $1 \mathrm{~h}$. After completion of the reaction, the crude mixture was stirred vigorously with $\mathrm{CH}_{2} \mathrm{Cl}_{2}(5 \mathrm{~mL})$ and $\mathrm{MeOH}(1 \mathrm{~mL})$, and then filtered. Other portions of $\mathrm{CH}_{2} \mathrm{Cl}_{2}$ could be used to remove thoroughly all the $\mathrm{CH}_{2} \mathrm{Cl}_{2}$ soluble materials from the solid residue. The solvent was removed under vacuum, and the residue was purified by flash silica gel column chromatography using hexane-ethyl acetate or hexane-TBME as eluent.

\section{$N$-Benzylthiobenzamide (2a) ${ }^{9}$}

Yield: $87 \%$ (by General procedure A), 77\% (by General procedure $\mathrm{C}$ ); yellow solid; $\mathrm{mp} 83{ }^{\circ} \mathrm{C}\left(\mathrm{CH}_{2} \mathrm{Cl}_{2}\right)$

IR (ATR): 3313, 3249, 1666, 1520, 1388, 1323, 1265, 1199, 1065, 933, $746,689 \mathrm{~cm}^{-1}$.

${ }^{1} \mathrm{H} \mathrm{NMR}\left(\mathrm{CDCl}_{3}, 300 \mathrm{MHz}\right): \delta=7.75-7.72\left(\mathrm{~m}, 3 \mathrm{H}, \mathrm{NH}\right.$ and $2 \times \mathrm{CH}_{\mathrm{ArCCS}}$ ), 7.44$7.33\left(\mathrm{~m}, 8 \mathrm{H}, 8 \times \mathrm{CH}_{\mathrm{Ar}}\right), 4.97\left(\mathrm{~d}, J=5.2 \mathrm{~Hz}, 2 \mathrm{H}, \mathrm{CH}_{2}\right)$.

${ }^{13} \mathrm{C} \mathrm{NMR}\left(\mathrm{CDCl}_{3}, 75 \mathrm{MHz}\right): \delta=199.3,141.7,136.3,131.3,129.1,128.6$, $128.5,128.3,126.8,51.1$.

MS (EI): $m / \mathrm{z}(\%)=250\left(\mathrm{M}^{+}, 11 \%\right), 194$ (40), 177 (19), 176 (15), 120 (16), 119 (23), 94 (13), 93 (100), 92 (10), 77 (16), 75 (15), 65 (11), 59 (69), 57 (51), 56 (42), 55 (16).

\section{4-Methoxy- $\boldsymbol{N}$-(4-methoxybenzyl)thiobenzamide (2b) ${ }^{25}$}

Yield: 87\% (by General procedure A); ochre crystals; mp $96{ }^{\circ} \mathrm{C}\left(\mathrm{CH}_{2} \mathrm{Cl}_{2}\right)$

IR (ATR): 3300, 1602, 1532, 1506, 1301, 1257, 1241, 1173, 1072, 1024, $932,838,815 \mathrm{~cm}^{-1}$.

${ }^{1} \mathrm{H} \mathrm{NMR}\left(\mathrm{CDCl}_{3}, 300 \mathrm{MHz}\right): \delta=7.75\left(\mathrm{~d}, J=8.8 \mathrm{~Hz}, 2 \mathrm{H}, 2 \times \mathrm{CH}_{\mathrm{Ar}} \mathrm{CCS}\right), 7.66(\mathrm{~s}$ br, $1 \mathrm{H}, \mathrm{NH}), 7.31\left(\mathrm{~d}, J=8.6 \mathrm{~Hz}, 2 \mathrm{H}, \mathrm{CH}_{\mathrm{Ar} C \mathrm{CH}_{2}}\right), 6.91-6.83(\mathrm{~m}, 4 \mathrm{H}$, $\mathrm{CH}_{\mathrm{Ar}} \mathrm{COCH}_{3}$ ), 4.90 (d, $J=4.9 \mathrm{~Hz}, 2 \mathrm{H}, \mathrm{CH}_{2}$ ), $3.81\left(\mathrm{~s}, 3 \mathrm{H}, \mathrm{CH}_{3}\right), 3.80(\mathrm{~s}, 3 \mathrm{H}$, $\mathrm{CH}_{3}$ ).

${ }^{13} \mathrm{C} \mathrm{NMR}\left(\mathrm{CDCl}_{3}, 75 \mathrm{MHz}\right): \delta=197.7,162.6,134.0,129.9,128.5$ (2 sings 128.6, 128.5), 114.5, 113.7, 55.6, 55.5, 50.7.

MS (EI): $m / z(\%)=287\left(\mathrm{M}^{+}, 34 \%\right), 151(19), 136(13), 134$ (17), 133 (25), 121 (100), 108 (11), 90 (15), 78 (16), 77 (19), 63 (11).

\section{$\boldsymbol{N}$-Phenethylthiobenzamide (2c) ${ }^{9}$}

Yield: 30\% (by General procedure A), 61\% (by General procedure B); yellow solid; $\mathrm{mp} 86^{\circ} \mathrm{C}\left(\mathrm{CH}_{2} \mathrm{Cl}_{2}\right)$

IR (ATR): 3296, 3060, 3028, 1528, 1486, 1451, 1382, 12447, 1181, 1092, $1065,1010,941 \mathrm{~cm}^{-1}$.

${ }^{1} \mathrm{H}$ NMR $\left(\mathrm{CDCl}_{3}, 300 \mathrm{MHz}\right): \delta=7.66-7.62\left(\mathrm{~m}, 3 \mathrm{H}, \mathrm{NH}\right.$ and $\left.2 \times \mathrm{CH}_{\mathrm{Ar}} \mathrm{CCS}\right), 7.46-$ $7.21\left(\mathrm{~m}, 8 \mathrm{H}, 8 \times \mathrm{CH}_{\mathrm{Ar}}\right.$, major rotamer), 7.13-6.96 (m, $8 \mathrm{H}, 8 \times \mathrm{CH}_{\mathrm{Ar}}$, minor rotamer), 4.13-4.07 (m, $2 \mathrm{H}, \mathrm{NHCH}_{2} \mathrm{CH}_{2} \mathrm{C}_{\mathrm{Ar}}$, major rotamer), 3.85 (q, $J=6.9$ $\mathrm{Hz}, 2 \mathrm{H}, \mathrm{NHCH}_{2} \mathrm{CH}_{2} \mathrm{C}_{\mathrm{Ar}}$, minor rotamer), $3.09(\mathrm{t}, J=7.0 \mathrm{~Hz}, 2 \mathrm{H}$, $\mathrm{NHCH}_{2} \mathrm{CH}_{2} \mathrm{C}_{\mathrm{Ar}}$, major rotamer), $2.83\left(\mathrm{t}, J=6.8 \mathrm{~Hz}, 2 \mathrm{H}, \mathrm{NHCH}_{2} \mathrm{CH}_{2} \mathrm{C}_{\mathrm{Ar}}\right.$, minor rotamer).

${ }^{13} \mathrm{C} \mathrm{NMR}\left(\mathrm{CDCl}_{3}, 75 \mathrm{MHz}\right): \delta=199.3,141.9,138.3,131.1,128.9$ (2C), 128.8 (2C), 128.5 (2C), 126.9, 126.7 (2C), 47.6, 33.9.

MS (EI): $m / \mathrm{z}(\%)=241\left(\mathrm{M}^{+}, 25 \%\right), 121$ (22), 105 (38), 104 (100), 103 (24), 91 (30), 77 (42), 51 (19).

4-Methyl- $\boldsymbol{N}$-(4-methylbenzyl)thiobenzamide (2d) ${ }^{25}$ 
Yield: 71\% (by General procedure A); yellow solid; mp $81{ }^{\circ} \mathrm{C}\left(\mathrm{CH}_{2} \mathrm{Cl}_{2}\right)$ IR (ATR): 3326, 2918, 1605, 1524, 1502, 1412, 1385, 1323, 1261, 1188, $1080,926 \mathrm{~cm}^{-1}$.

$\left.{ }^{1} \mathrm{H} \mathrm{NMR} \mathrm{(} \mathrm{CDCl}_{3}, 300 \mathrm{MHz}\right): \delta=7.66-7.64\left(\mathrm{~m}, 3 \mathrm{H}, \mathrm{NH}\right.$ and $\left.2 \times \mathrm{CH}_{\mathrm{Ar}} \mathrm{CCS}\right), 7.27$ $\left(\mathrm{m}, 2 \mathrm{H}, 2 \times \mathrm{CH}_{\mathrm{Ar}}\right), 7.29-7.26\left(\mathrm{~m}, 4 \mathrm{H}, 4 \times \mathrm{CH}_{\mathrm{Ar}}\right), 4.92\left(\mathrm{~d}, J=4.9 \mathrm{~Hz}, 2 \mathrm{H}, \mathrm{CH}_{2}\right)$ $2.35\left(\mathrm{~s}, 6 \mathrm{H}, 2 \times \mathrm{CH}_{3}\right)$.

${ }^{13} \mathrm{C} \mathrm{NMR}\left(\mathrm{CDCl}_{3}, 75 \mathrm{MHz}\right): \delta=198.7,141.8,138.9,138.1,133.3,129.8$ (2C), 129.2(2C), 128.5(2C), 126.8(2C), 50.9, 21.4, 21.3.

MS (EI): $m / \mathrm{z}(\%)=256\left(\mathrm{M}^{+}+1,19 \%\right), 255\left(\mathrm{M}^{+}, 100\right), 222$ (21), 136 (15), 135 (48), 121 (13), 120 (43), 118 (31), 105 (92), 103 (16), 91 (40), 89 (11), 79 (15), 77 (28), 65 (16).

\section{3-Methyl- $N$-(3-methylbenzyl)thiobenzamide (2e)}

Yield: 50\% (by General procedure A); yellow oil

IR (ATR): 3293, 2980, 2920, 1737, 1521, 1372, 1326, 1242, 1044, 960, $825,790 \mathrm{~cm}^{-1}$.

${ }^{1} \mathrm{H} \mathrm{NMR}\left(\mathrm{CDCl}_{3}, 300 \mathrm{MHz}\right): \delta=7.69(\mathrm{~s} \mathrm{br}, 1 \mathrm{H}, \mathrm{NH}), 7.60\left(\mathrm{~s}, 1 \mathrm{H}, \mathrm{CH}_{\mathrm{ArCCS}}\right.$, 7.51-7.49 (m, $\left.1 \mathrm{H}, \mathrm{CH}_{\mathrm{Ar}} \mathrm{CCH}_{2}\right), 7.28-7.17\left(\mathrm{~m}, 6 \mathrm{H}, 6 \times \mathrm{CH}_{\mathrm{Ar}}\right), 4.93(\mathrm{~d}, J=5.0 \mathrm{~Hz}$ $\left.2 \mathrm{H}, \mathrm{CH}_{2}\right), 2.37\left(\mathrm{~s}, 6 \mathrm{H}, 2 \times \mathrm{CH}_{3}\right)$.

${ }^{13} \mathrm{C} \mathrm{NMR}\left(\mathrm{CDCl}_{3}, 75 \mathrm{MHz}\right): \delta=199.3,141.8,138.9,138.5,136.2,132.0$, 129.3, 129.1, 129.0, 128.5, 127.8, 125.5, 123.6, 51.2, 21.5, 21.4.

MS (EI): $m / \mathrm{z}(\%)=256\left(\mathrm{M}^{+}+1,19 \%\right), 255\left(\mathrm{M}^{+}, 100\right), 222$ (21), 136 (15), 135 (48), 121 (13), 120 (43), 118 (31), 105 (92), 103 (16), 91 (40), 89 (11), 79 (15), 77 (28), 65 (16).

HRMS (ESI): $m / z$ [M+H] ${ }^{+}$calcd for $\mathrm{C}_{16} \mathrm{H}_{17} \mathrm{NS}$ : 255.1082; found: 255.1061 . $\boldsymbol{N}$-(1-Phenylethyl)-2-phenylthioacetamide (2f) ${ }^{26}$

Yield: 40\% (by General procedure A); orange solid; mp $104{ }^{\circ} \mathrm{C}\left(\mathrm{CH}_{2} \mathrm{Cl}_{2}\right)$ IR (ATR): 3171, 3025, 1531, 1493, 1454, 1435, 1407, 1160, 1106, 1078, $761,718,711 \mathrm{~cm}^{-1}$.

${ }^{1} \mathrm{H} \mathrm{NMR}\left(\mathrm{CDCl}_{3}, 300 \mathrm{MHz}\right): \delta=7.40-7.23\left(\mathrm{~m}, 9 \mathrm{H}, \mathrm{NH}\right.$ and $\left.9 \times \mathrm{CH}_{\mathrm{Ar}}\right), 7.17-$ $7.14\left(\mathrm{~m}, 2 \mathrm{H}, \mathrm{CH}_{\mathrm{ArCH}}\right.$ ), 7.73 (p, $J=7.0 \mathrm{~Hz}, 4.12\left(\mathrm{~s}, 2 \mathrm{H}, \mathrm{CH}_{2}\right), 1.49$ and 1.46 $\left(2 \mathrm{~s}, 3 \mathrm{H}, \mathrm{CH}_{3}\right.$, both rotamers).

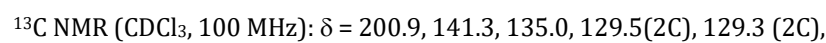
128.8 (2C), 127.9, 127.8, 126.3 (2C), 54.5, 53.4, 20.3

MS (EI): $m / \mathrm{z}(\%)=255\left(\mathrm{M}^{+}, 26 \%\right), 106$ (11), 105 (100), 104 (22), 103 (18), 91 (34), 79 (16), 78 (11), 77 (26), 65 (12).

\section{$\boldsymbol{N}$-Benzyl- $\boldsymbol{N}$-methylthiobenzamide (2g) ${ }^{14}$}

Yield: 63\% (by General procedure A); yellow oil

IR (ATR): 2924, 1496, 1482, 1452, 1395, 1290, 1212, 1110, 1082, 1072, $762,735,695 \mathrm{~cm}^{-1}$.

${ }^{1} \mathrm{H} \mathrm{NMR}\left(\mathrm{CDCl}_{3}, 300 \mathrm{MHz}\right): \delta=7.46-7.30\left(\mathrm{~m}, 9 \mathrm{H}, 9 \times \mathrm{CH}_{\mathrm{Ar}}\right), 7.13-7.10(\mathrm{~m}$, $\left.1 \mathrm{H}, 1 \times \mathrm{CH}_{\mathrm{Ar}}\right), 5.44\left(\mathrm{~s}, 2 \mathrm{H}, \mathrm{CH}_{2}\right.$, major rotamer), $4.71\left(\mathrm{~s}, 2 \mathrm{H}, \mathrm{CH}_{2}\right.$, minor rotamer), $3.47\left(\mathrm{~s}, 3 \mathrm{H}, \mathrm{CH}_{3}\right.$, major rotamer), $3.00\left(\mathrm{~s}, 3 \mathrm{H}, \mathrm{CH}_{3}\right.$, minor rotamer).

${ }^{13} \mathrm{C} \mathrm{NMR}\left(\mathrm{CDCl}_{3}, 75 \mathrm{MHz}\right): \delta=202.5,202.4,143.5,143.4,135.5,135.3$, $131.2,129.1129 .0,128.7,128.5,128.1,127.0,125.8,125.6,59.5,57.5$ 41.3, 41.1.

MS (EI): $m / \mathrm{z}(\%)=241\left(\mathrm{M}^{+}, 37 \%\right), 240$ (34), 208 (13), 121 (100), 118 (16), 104 (15), 91 (40), 77 (37), 65 (20), 51 (16).

\section{4-Chloro- $\boldsymbol{N}$-(4-chlorobenzyl)thiobenzamide $(2 \mathrm{~h})^{25}$}

Yield: 72\% (by General procedure A); yellow oil

IR (ATR): 3239, 1589, 1528, 1485, 1402, 1329, 1281, 1209, 1082, 1012 $924,833,808 \mathrm{~cm}^{-1}$.

${ }^{1} \mathrm{H} \mathrm{NMR}\left(\mathrm{CDCl}_{3}, 300 \mathrm{MHz}\right): \delta=7.80(\mathrm{~s} \mathrm{br}, 1 \mathrm{H}, \mathrm{NH}), 7.67-7.64(\mathrm{~m}, 2 \mathrm{H}$, $2 \times \mathrm{CH}_{\mathrm{ArCCS}}$ ), 7.36-7.28 (m, $\left.6 \mathrm{H}, 6 \times \mathrm{CH}_{\mathrm{Ar}}\right), 4.93\left(\mathrm{~d}, J=5.2 \mathrm{~Hz}, 2 \mathrm{H}, \mathrm{CH}_{2}\right)$.

${ }^{13} \mathrm{C} \mathrm{NMR}\left(\mathrm{CDCl}_{3}, 75 \mathrm{MHz}\right): \delta=197.9,139.7,137.6,134.6,134.2,129.8$, $129.3,128.8,128.2,50.2$.

MS (EI): $m / \mathrm{z}(\%)=297\left(\mathrm{M}^{+}+2,30 \%\right), 295\left(\mathrm{M}^{+}, 55\right), \mathrm{M}^{+}-1297(30), 296$ (37), 295 (55), 294 (34), 279 (19), 157 (26), 156 (31), 155 (48), 142 (17),
141 (20), 140 (53), 139 (64), 138 (53), 137 (73), 127 (40), 126 (21), 125 (100), 114 (18), 112 (15), 111 (41), 111 (41), 102 (34), 99 (17), 89 (40), 77 (24), 76 (25), 75 (52), 74 (27), 73 (17), 63 (24), 51 (34).

4-Fluoro- $\boldsymbol{N}$-(4-fluorobenzyl)thiobenzamide $(\mathbf{2 i})^{25}$

Yield: 63\% (by General procedure A); yellow oil

IR (ATR): 3249, 1595, 1536, 1498, 1413, 1290, 1243, 1219, 1154, 1079, $919,846,817 \mathrm{~cm}^{-1}$.

${ }^{1} \mathrm{H}$ NMR $\left(\mathrm{CDCl}_{3}, 300 \mathrm{MHz}\right): \delta=7.77-7.73\left(\mathrm{~m}, 3 \mathrm{H}, \mathrm{NH}\right.$ and $\left.2 \times \mathrm{CH}_{\mathrm{Ar}} \mathrm{CCS}\right), 7.36$ (dd, $J=8.7$ and $5.3 \mathrm{~Hz}, 2 \mathrm{H}, 2 \times \mathrm{CH}_{\mathrm{Ar}}$ ), $7.05\left(\mathrm{q}, J=8.7 \mathrm{~Hz}, 4 \mathrm{H}, 4 \times \mathrm{CH}_{\mathrm{Ar}} \mathrm{F}\right.$ ), 4.94 (d, $J=5.2 \mathrm{~Hz}, 2 \mathrm{H}, \mathrm{CH}_{2}$ ).

${ }^{13} \mathrm{C} \mathrm{NMR}\left(\mathrm{CDCl}_{3}, 75 \mathrm{MHz}\right): \delta=197.8,164.6(\mathrm{~d}, J=252.5 \mathrm{~Hz}), 162.6(\mathrm{~d}, J=$ $247.5 \mathrm{~Hz}), 137.7$ (d, $J=3.0 \mathrm{~Hz}), 132.0$ (d, $J=3.2 \mathrm{~Hz}), 130.3$ (d, $J=8.2 \mathrm{~Hz}$ ), $129.0(\mathrm{~d}, J=8.8 \mathrm{~Hz}), 116.0$ (d, $J=21.5 \mathrm{~Hz}), 115.6(\mathrm{~d}, J=22.0 \mathrm{~Hz}), 50.3$.

MS (EI): $m / z(\%)=263\left(\mathrm{M}^{+}, 57 \%\right), 247$ (13), 140 (14), 139 (46), 124 (21), 123 (43), 122 (28), 121 (33), 109 (100), 96 (13), 95 (38), 94 (15), 83 (20), 75 (27), 50 (13).

\section{$N$-(Thiobenzoyl)morpholine (2j) $)^{27}$}

Yield: 73\% (by General procedure B); yellow solid; mp $122{ }^{\circ} \mathrm{C}\left(\mathrm{CH}_{2} \mathrm{Cl}_{2}\right)$

IR (ATR): 2920, 2848, 1478, 1432, 1290, 1254, 1225, 1205, 1111, 1061, $991,871,758 \mathrm{~cm}^{-1}$.

${ }^{1} \mathrm{H}$ NMR $\left(\mathrm{CDCl}_{3}, 300 \mathrm{MHz}\right): \delta=7.42-7.27\left(\mathrm{~m}, 5 \mathrm{H}, 5 \times \mathrm{CH}_{\mathrm{Ar}}\right), 4.47-4.43$ and 3.91-3.88 (2m, 4H, $\left.\mathrm{CH}_{2} \mathrm{NCH}_{2}\right)$, 3.66-3.60 (m, $\left.4 \mathrm{H}, \mathrm{CH}_{2} \mathrm{OCH}_{2}\right)$.

$\left.{ }^{13} \mathrm{C} \mathrm{NMR} \mathrm{(} \mathrm{CDCl}_{3}, 75 \mathrm{MHz}\right): \delta=201.0,142.5,128.9,128.6$ (2C), 125.9 (2C), $66.8,66.6,52.6,49.6,33.8$.

MS (EI): $m / \mathrm{z}(\%)=207\left(\mathrm{M}^{+}, 43 \%\right), 206\left(\mathrm{M}^{+}-1,20\right), 176(12), 122(14), 121$ (100), 104 (20), 86 (16), 77 (47), 51 (20).

\section{$\boldsymbol{N}$-(4-Chlorothiobenzoyl)morpholine (2k) ${ }^{8 \mathrm{c}}$}

Yield: 73\% (by General procedure B); yellow oil

IR (ATR): 2967, 2921, 2855, 1592, 1472, 1435, 1289, 1258, 1228, 1113, 1034, 996, 819, $726 \mathrm{~cm}^{-1}$.

${ }^{1} \mathrm{H} \mathrm{NMR}\left(\mathrm{CDCl}_{3}, 300 \mathrm{MHz}\right): \delta=7.36-7.32\left(\mathrm{~m}, 2 \mathrm{H}, 2 \times \mathrm{CH}_{\mathrm{Ar}}\right), 7.25-7.22(\mathrm{~m}$, $\left.2 \mathrm{H}, 2 \times \mathrm{CH}_{\mathrm{Ar}}\right), 4.43-4.40$ and $3.90-3.86\left(2 \mathrm{~m}, 4 \mathrm{H}, \mathrm{CH}_{2} \mathrm{NCH}_{2}\right), 3.66-3.60(\mathrm{~m}$, $4 \mathrm{H}, \mathrm{CH}_{2} \mathrm{OCH}_{2}$ ).

${ }^{13} \mathrm{C} \mathrm{NMR}\left(\mathrm{CDCl}_{3}, 75 \mathrm{MHz}\right): \delta=199.6,140.8,135.0,128.9$ (2C), 127.5 (2C), $66.8,66.6,52.7,49.7$.

MS (EI): $m / \mathrm{z}(\%)=243\left(\mathrm{M}^{+}+2,29 \%\right), 242\left(\mathrm{M}^{+}+1,21\right), 241\left(\mathrm{M}^{+}, 80\right), 240$ $\left(\mathrm{M}^{+}-1,29\right), 210$ (19), 208 (12), 198 (13), 157 (39), 156 (18), 155 (100), 139 (28), 138 (16), 120 (11), 111 (20), 86 (20), 75 (12).

\section{$N$-(Thiobenzoyl)pyrrolidine (2l) ${ }^{8 b}$}

Yield: $42 \%$ (by General procedure B); brown pale solid; mp $79^{\circ} \mathrm{C}\left(\mathrm{CH}_{2} \mathrm{Cl}_{2}\right)$ IR (ATR): 2982, 1614, 1496, 1470, 1449, 1326, 1264, 1004, 957, 919, 877, $764 \mathrm{~cm}^{-1}$.

${ }^{1} \mathrm{H}$ NMR $\left(\mathrm{CDCl}_{3}, 300 \mathrm{MHz}\right): \delta=7.38-7.34\left(\mathrm{~m}, 5 \mathrm{H}, 5 \times \mathrm{CH}_{\mathrm{Ar}}\right), 3.98$ and 3.47 $\left(2 \mathrm{t}, J=7.0 \mathrm{~Hz}\right.$ and $\left.6.7 \mathrm{~Hz}, 4 \mathrm{H}, \mathrm{CH}_{2} \mathrm{NCH}_{2}\right), 2.11-2.07$ and $2.00-1.95(2 \mathrm{~m}, 4 \mathrm{H}$, $\mathrm{CH}_{2} \mathrm{CH}_{2}$ ).

${ }^{13} \mathrm{C} \mathrm{NMR}\left(\mathrm{CDCl}_{3}, 75 \mathrm{MHz}\right): \delta=197.4,144.1,128.8,128.4,125.8,53.9,53.5$, 26.6, 24.8.

MS (EI): $m / \mathrm{z}(\%)=191\left(\mathrm{M}^{+}, 97 \%\right), 190\left(\mathrm{M}^{+}-1,43\right), 158(26), 131(11), 130$ (100), 122 (19), 121 (81), 105 (13), 104 (44), 77 (51), 70 (30), 55 (15), 51 (23).

\section{$N$-Octylthiobenzamide $(2 \mathrm{~m})^{28}$}

Yield: 82\% (by General procedure B); brown oil

IR (ATR): 2925, 2846, 1523, 1449, 1335, 768, $692 \mathrm{~cm}^{-1}$

${ }^{1} \mathrm{H} \mathrm{NMR}\left(\mathrm{CDCl}_{3}, 300 \mathrm{MHz}\right): \delta=7.73-7.70\left(\mathrm{~m}, 2 \mathrm{H}, 2 \times \mathrm{CH}_{\mathrm{ArCCS}}\right), 7.64(\mathrm{~s} \mathrm{br}$, $1 \mathrm{H}, \mathrm{NH}), 7.45-7.34\left(\mathrm{~m}, 3 \mathrm{H}, 3 \times \mathrm{CH}_{\mathrm{Ar}}\right), 3.83-3.76\left(\mathrm{~m}, 2 \mathrm{H}, \mathrm{NHCH}_{2}\right), 1.79-1.70$ (m, $\left.2 \mathrm{H}, \mathrm{NHCH}_{2} \mathrm{CH}_{2}\right), 1.45-1.28\left(\mathrm{~m}, 10 \mathrm{H}, 5 \times \mathrm{CH}_{2}\right), 0.91-0.86\left(\mathrm{~m}, 3 \mathrm{H}, \mathrm{CH}_{3}\right)$. 
$\left.{ }^{13} \mathrm{C} \mathrm{NMR} \mathrm{(} \mathrm{CDCl}_{3}, 75 \mathrm{MHz}\right): \delta=205.5,199.5,142.2,131.0,128.6(2 \mathrm{C}), 126.7$ (2C), 47.5, 47.0, 46.3, 31.9, 31.8, 29.5, 29.4, 29.3, 29.2, 29.1, 29.0, 28.3, 28.2, $27.2,27.1,22.8,22.7,14.2$ (26 C, both rotamers).

MS (EI): $m / z(\%)=249\left(\mathrm{M}^{+}, 14 \%\right), 227$ (17), 216 (38), 151 (20), 150 (39), 122 (13), 121 (100), 105 (12), 104 (46), 91 (18), 77 (31).

\section{N-Octyl-4-methoxythiobenzamide (2n) ${ }^{9}$}

Yield: 76\% (by General procedure B); brown oil

IR (ATR): 3328, 2960, 2913, 2848, 1605, 1532, 1501, 1469, 1421, 1258, $1191,1029,936 \mathrm{~cm}^{-1}$.

${ }^{1} \mathrm{H} \mathrm{NMR}\left(\mathrm{CDCl}_{3}, 300 \mathrm{MHz}\right): \delta=7.74\left(\mathrm{~d}, J=8.9 \mathrm{~Hz}, 2 \mathrm{H}, 2 \times \mathrm{CH}_{\mathrm{ArCCS}}\right), 7.58(\mathrm{~s}$ br, $1 \mathrm{H}, \mathrm{NH}), 6.86\left(\mathrm{~d}, J=8.9 \mathrm{~Hz}, 2 \mathrm{H}, 2 \times \mathrm{CH}_{\mathrm{Ar}}\right), 3.83\left(\mathrm{~s}, 3 \mathrm{H}, \mathrm{CH}_{3}\right), 3.81-3.76(\mathrm{~m}$, $\left.2 \mathrm{H}, \mathrm{NHCH}_{2}\right), 1.77-1.72\left(\mathrm{~m}, 10 \mathrm{H}, 5 \times \mathrm{CH}_{2}\right), 0.91-0.86\left(\mathrm{~m}, 3 \mathrm{H}, \mathrm{CH}_{3}\right)$.

${ }^{13} \mathrm{C} \mathrm{NMR}\left(\mathrm{CDCl}_{3}, 75 \mathrm{MHz}\right): \delta=197.9,162.1,134.4,128.5$ (2C), 113.7 (2C), $55.6,47.0,31.9,29.4,29.3,28.3,27.2,22.7,14.2$.

MS (EI): $m / \mathrm{z}(\%)=275\left(\mathrm{M}^{+}, 48 \%\right), 278$ (21), 246 (78), 207 (13), 181 (36), 180 (51), 152 (14), 151 (100), 136 (13), 135 (21), 134 (76).

\section{$N$-Phenethyl-4-methoxythiobenzamide (2o)}

Yield: $61 \%$ (by General procedure B); yellow solid; mp $120^{\circ} \mathrm{C}\left(\mathrm{CH}_{2} \mathrm{Cl}_{2}\right)$

IR (ATR): 3340, 3009, 2933, 1599, 1533, 1504, 1387, 1299, 1246, 1180, $1028,838,748 \mathrm{~cm}^{-1}$.

${ }^{1} \mathrm{H} \mathrm{NMR}\left(\mathrm{CDCl}_{3}, 300 \mathrm{MHz}\right): \delta=7.64\left(\mathrm{~d}, J=8.9 \mathrm{~Hz}, 2 \mathrm{H}, 2 \times \mathrm{CH}_{\mathrm{ArCCS}}\right), 7.53(\mathrm{~s}$ br, $1 \mathrm{H}, \mathrm{NH}), 7.37-7.32\left(\mathrm{~m}, 2 \mathrm{H}, 2 \times \mathrm{CH}_{\mathrm{Ar}}\right), 7.28-7.24\left(\mathrm{~m}, 2 \mathrm{H}, 2 \times \mathrm{CH}_{\mathrm{Ar}}\right), 6.83(\mathrm{~d}$, $\left.J=8.9 \mathrm{~Hz}, 2 \mathrm{H}, 2 \times \mathrm{CH}_{\mathrm{Ar}}\right), 4.09\left(\mathrm{q}, J=6.9 \mathrm{~Hz}, 2 \mathrm{H}, \mathrm{NHCH}_{2} \mathrm{CH}_{2} \mathrm{C}_{\mathrm{Ar}}\right), 3.07(\mathrm{t}, J=$ $6.9 \mathrm{~Hz}, 2 \mathrm{H}, \mathrm{NHCH}_{2} \mathrm{CH}_{2} \mathrm{C}_{\mathrm{Ar}}$ ).

${ }^{13} \mathrm{C} \mathrm{NMR}\left(\mathrm{CDCl}_{3}, 75 \mathrm{MHz}\right): \delta=198.1,162.2,138.4,134.2,129.0,128.9$, $128.5,126.9,113.7,55.6,47.5,34.0$.

MS (EI): $m / \mathrm{z}(\%)=271\left(\mathrm{M}^{+}, 38 \%\right), 151(21), 136$ (14), 135 (46), 134 (100), 104 (22), 92 (11), 91 (36), 77 (21), 65 (19), 63 (12).

HRMS (ESI): $m / z$ [M+H] ${ }^{+}$calcd for $\mathrm{C}_{16} \mathrm{H}_{17} \mathrm{NOS}: 271.1031$; found: 271.1001 .

\section{$\boldsymbol{N}$-Phenethyl-4-chlorothiobenzamide (2p) ${ }^{27}$}

Yield: 54\% (by General procedure B); yellow solid; mp $85^{\circ} \mathrm{C}\left(\mathrm{CH}_{2} \mathrm{Cl}_{2}\right)$

IR (ATR): 3270, 1589, 1522, 1485, 1405, 1339, 1234, 1178, 1089, 1063, $1011,937,841 \mathrm{~cm}^{-1}$.

${ }^{1} \mathrm{H} \mathrm{NMR}\left(\mathrm{CDCl}_{3}, 300 \mathrm{MHz}\right): \delta=7.61-7.57\left(\mathrm{~m}, 3 \mathrm{H}, \mathrm{NH}\right.$ and $\left.2 \times \mathrm{CH}_{\mathrm{ArCCS}}\right), 7.40$ $7.27\left(\mathrm{~m}, 7 \mathrm{H}, 7 \times \mathrm{CH}_{\mathrm{Ar}}\right), 4.11\left(\mathrm{td}, J=6.9\right.$ and $5.7 \mathrm{~Hz}, 2 \mathrm{H}, \mathrm{NHCH}_{2} \mathrm{CH}_{2} \mathrm{C}_{\mathrm{Ar}}$, major rotamer), $3.75\left(\mathrm{t}, J=7.0 \mathrm{~Hz}, 2 \mathrm{H}, \mathrm{NHCH}_{2} \mathrm{CH}_{2} \mathrm{C}_{\mathrm{Ar}}\right.$, minor rotamer), $3.10(\mathrm{t}, J=$ $6.9 \mathrm{~Hz}, 2 \mathrm{H}, \mathrm{NHCH}_{2} \mathrm{CH}_{2} \mathrm{C}_{\mathrm{Ar}}$, major rotamer), $3.01(\mathrm{t}, J=6.9 \mathrm{~Hz}, 2 \mathrm{H}$, $\mathrm{NHCH}_{2} \mathrm{CH}_{2} \mathrm{C}_{\mathrm{Ar}}$, minor rotamer).

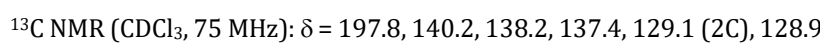
(2C), 128.8 (2C), $128.0(2 \mathrm{C}), 127.1,47.6,33.9$.

MS (EI): $m / \mathrm{z}(\%)=277\left(\mathrm{M}^{+}+2,14 \%\right), 275\left(\mathrm{M}^{+}, 35\right), 155$ (25), 139 (19), 105 (11), 104 (100).

\section{$N$-Phenethyl-4-fluorothiobenzamide (2q)}

Yield: $41 \%$ (by General procedure B); yellow solid; mp $120{ }^{\circ} \mathrm{C}\left(\mathrm{CH}_{2} \mathrm{Cl}_{2}\right)$

IR (ATR): 3300, 1599, 1534, 1502, 1244, 1182, 1162, 1065, 1011, 940 , $840,741,696 \mathrm{~cm}^{-1}$.

${ }^{1} \mathrm{H}$ NMR $\left(\mathrm{CDCl}_{3}, 300 \mathrm{MHz}\right): \delta=7.65-7.60\left(\mathrm{~m}, 3 \mathrm{H}, \mathrm{NH}\right.$ and $\left.2 \times \mathrm{CH}_{\mathrm{Ar}} \mathrm{CCS}\right), 7.35-$ 7.24 and 7.03-6.97 $\left(2 \mathrm{~m}, 7 \mathrm{H}, 7 \times \mathrm{CH}_{\mathrm{Ar}}\right), 4.11-4.04\left(\mathrm{~m}, 2 \mathrm{H}, \mathrm{NHCH}_{2} \mathrm{CH}_{2} \mathrm{C}_{\mathrm{Ar}}\right.$, major rotamer), $3.84\left(\mathrm{t}, J=6.6 \mathrm{~Hz}, 2 \mathrm{H}, \mathrm{NHCH}_{2} \mathrm{CH}_{2} \mathrm{C}_{\mathrm{Ar}}\right.$, minor rotamer), 3.07 ( $\mathrm{t}, J=7.0 \mathrm{~Hz}, 2 \mathrm{H}, \mathrm{NHCH}_{2} \mathrm{CH}_{2} \mathrm{C}_{\mathrm{Ar}}$, major rotamer), $2.82(\mathrm{t}, J=6.8 \mathrm{~Hz}, 2 \mathrm{H}$, $\mathrm{NHCH}_{2} \mathrm{CH}_{2} \mathrm{C}_{\mathrm{Ar}}$, minor rotamer).

${ }^{13} \mathrm{C} \mathrm{NMR}\left(\mathrm{CDCl}_{3}, 75 \mathrm{MHz}\right): \delta=197.8,164.5(\mathrm{~d}, J=252.1 \mathrm{~Hz}), 138.2,138.0$ $(\mathrm{d}, J=3.0 \mathrm{~Hz}), 129.0(2 \mathrm{C}), 128.9(\mathrm{~d}, J=8.6 \mathrm{~Hz}), 128.8(2 \mathrm{C}), 127.0,115.5(\mathrm{~d}$, $J=21.9 \mathrm{~Hz}), 47.6,33.8$.

MS (EI): $m / \mathrm{z}(\%)=259\left(\mathrm{M}^{+}, 19 \%\right), 139$ (45), 123 (14), 122 (13), 105 (11), 104 (100), 103 (17), 95 (23), 91 (20), 78 (11).

HRMS (ESI): $m / z$ [M+H] ${ }^{+}$calcd for $\mathrm{C}_{15} \mathrm{H}_{14} \mathrm{FNS}$ : 259.0831; found: 259.0837

\section{$N$-Methylthiobenzamide (3) ${ }^{14}$}

Yield: 87\% (by General procedure C); brown solid; mp $77^{\circ} \mathrm{C}\left(\mathrm{CH}_{2} \mathrm{Cl}_{2}\right)$ IR (ATR): 3311, 1537, 1488, 1458, 1357, 1235, 1042, 1026, 998, 940, 920, $773,686 \mathrm{~cm}^{-1}$.

${ }^{1} \mathrm{H}$ NMR $\left(\mathrm{CDCl}_{3}, 300 \mathrm{MHz}\right): \delta=7.93(\mathrm{~s} \mathrm{br}, 1 \mathrm{H}, \mathrm{NH}), 7.72-7.69(\mathrm{~m}, 2 \mathrm{H}$, $\left.2 \times \mathrm{CH}_{\mathrm{Ar}} \mathrm{CCS}\right), 7.43-7.32\left(\mathrm{~m}, 3 \mathrm{H}, 3 \times \mathrm{CH}_{\mathrm{Ar}}\right), 3.30\left(\mathrm{~s}, 3 \mathrm{H}, \mathrm{CH}_{3}\right.$, major rotamer), $3.28\left(\mathrm{~s}, 3 \mathrm{H}, \mathrm{CH}_{3}\right.$, minor rotamer).

${ }^{13} \mathrm{C} \mathrm{NMR}\left(\mathrm{CDCl}_{3}, 75 \mathrm{MHz}\right): \delta=200.0,141.6,131.1,128.5$ (2C), 126.7 (2C), 33.8 .

MS (EI): $m / \mathrm{z}(\%)=152\left(\mathrm{M}^{+}+1,13\right), 151\left(\mathrm{M}^{+}, 100\right), 150(85), 122(12), 121$ (89), 118 (32), 117 (19), 105 (12), 104 (13), 77 (65), 74 (27), 51 (37).

\section{1,2,3,4-Tetrahydroisoquinoline-1-thione (4) ${ }^{25}$}

Yield: $52 \%$ (by General procedure C); yellow solid; mp $85^{\circ} \mathrm{C}\left(\mathrm{CH}_{2} \mathrm{Cl}_{2}\right)$

IR (ATR): 3168, 3036, 1580, 1541, 1345, 1248, 1207, 1196, 1011, 928, $865,768,733 \mathrm{~cm}^{-1}$.

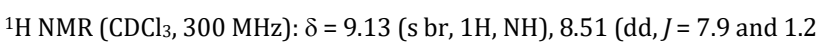
$\mathrm{Hz}, 1 \mathrm{H}, 1 \times \mathrm{CH}_{\mathrm{Ar}} \mathrm{CCS}$ ), 7.46 (td, $J=7.4$ and $1.4 \mathrm{~Hz}, 1 \mathrm{H}, 1 \times \mathrm{CH}_{\mathrm{Ar}} \mathrm{CH}_{\mathrm{Ar}} \mathrm{CS}$ ), 7.35

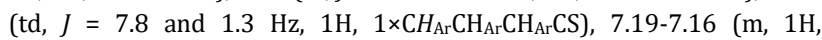
$1 \times \mathrm{CH}_{\mathrm{ArCCH}}$ ) , $3.57\left(\mathrm{td}, J=6.9\right.$ and $\left.3.5 \mathrm{~Hz}, 2 \mathrm{H}, \mathrm{CCH}_{2} \mathrm{CH}_{2} \mathrm{NH}\right), 3.57(\mathrm{t}, J=6.8$ $\mathrm{Hz}, 2 \mathrm{H}, \mathrm{CCH}_{2} \mathrm{CH}_{2} \mathrm{NH}$ ).

${ }^{13} \mathrm{C} \mathrm{NMR}\left(\mathrm{CDCl}_{3}, 75 \mathrm{MHz}\right): \delta=193.9,134.0,132.8,132.4,132.0,127.4$, 127.2, 41.9, 27.9 .

MS (EI): $m / \mathrm{z}(\%)=165\left(\mathrm{M}^{+}+2,12 \%\right), 164\left(\mathrm{M}^{+}+1,13\right), 163\left(\mathrm{M}^{+}, 100\right), 162$ (14), 136 (13), 135 (25), 134 (90), 131 (12), 130 (23), 128 (28), 118 (17), 90 (20), 89 (20), 77 (21), 63 (21).

\section{Funding Information}

This work was financially supported by the Spanish Ministry (Ministerio de Economía y Competitividad CTQ2015-66624-P) and the University of Alicante (VIGROB-285).

\section{Acknowledgment}

The authors thank MSc. M. Albert-Soriano and Dr. P. Trillo for fruitful discussions.

\section{References}

(1) Lebel, H. Sci. Synth. 2005, 22, 141.

(2) Suzuki, Y.; Iwata, M.; Yazaki, R.; Kumagai, N.; Shibasaki, M. J. Org. Chem. 2012, 77, 4496.

(3) (a) Guo, W.-S.; Wen, L.-R.; Li, M. Org. Biomol. Chem. 2015, 13, 1942. (b) Nguyen, T. B.; Ermolenko, L.; Dean, W. A.; Al-Mourabit, A. Org. Lett. 2012, 14, 5948.

(4) Gopinath, P.; Watanabe, T.; Shibasaki, M. J. Org. Chem. 2012, 77, 9260.

(5) (a) Banala, S.; Süssmuth, R. D. ChemBioChem 2010, 11, 1335. (b) Wang, F.; Langley, R.; Gulten, G.; Dover, L. G.; Besra, G. S.; Jacobs, Jr., W. R.; Sacchettini, J. C. J. Exp. Med. 2007, 204, 73. (c) Quemard, A.; Laneelle, G.; C. Lacave, G. Antimicrob. Agents Chemother. 1992, 36, 1316.

(6) Wang, Y. J.; Szantai-Kis, D. M.; Petersson, E. J. Org. Biomol. Chem. 2015, 13, 5074 .

(7) Schaumann, E. In Comprehensive Organic Synthesis II (Second Edition), Elsevier, Amsterdam, 2014, 411.

(8) (a) Wei, J.; Li, Y.; Jiang, X. Org. Lett. 2016, 18, 340. (b) Chen, S.; Li, Y.; Chen, J.; Xu, X.; Su, L.; Tang, Z.; Au, C.-T.; Qiu, R. Synlett 2016, 27, 2339. (c) Wang, X.; Ji, M.; Lim, S.; Jang, H.-Y. J. Org. Chem. 2014, 79, 7256.

(9) Curphey, T. J.J. Org. Chem. 2002, 67, 6461.

(10) (a) Cava, M. P.; Levinson, M. I. Tetrahedron 1985, 41, 5061. (b) Ozturk, T.; Ertas, E.; Mert, O. Chem. Rev. 2007, 107, 5210.

(11) (a) Kindler, K. Liebigs Ann. Chem. 1923, 431, 187. (b) Priebbenow, D. L.; Bolm, C. Chem. Soc. Rev. 2013, 42, 7870. 
(12) a) T. B. Nguyen, L. Ermolenko, A. Al-Mourabit, Org. Lett. 2012, 14 4274-4277; b) Nguyen, T. B. Adv. Synth. Catal. 2017, 359, 10661130.

(13) (a) Microwave Heating as a Tool for Sustainable Chemistry (Ed. N. E. Leadbeater), CRC Press, Boca Raton, 2011. (b) Practical Microwave Synthesis for Organic Chemists (Eds. C. O. Kappe, D. Dallinger, S. S. Murphree), Wiley-VCH, Weinheim, 2009. (c) Microwaves in Organic Synthesis (Ed. A. Loupy), Wiley-VCH, Weinheim, 2002

(14) Milen, M.; Abranyi-Balogh, P.; Dancso, A.; Keglevich, G. J. Sulfur Chem. 2012, 33, 33.

(15) O. I. Zbruyev, N. Stiasni, C. O. Kappe, J. Comb. Chem. 2003, 5, 145 148.

(16) (a) Allegue, A.; Albert-Soriano, M.; Pastor, I. M. Appl. Organomet. Chem. 2015, 29, 624. (b) Gisbert, P.; Trillo, P.; Pastor, I. M. ChemistrySelect 2018, 3, 887.

(17) Albert-Soriano, M.; Pastor, I. M. Eur. J. Org. Chem. 2016, 5180.

(18) Albert-Soriano, M.; Trillo, P.; Soler, T.; Pastor, I. M. Eur. J. Org. Chem. 2017, 6375.

(19) Trillo, P.; Pastor, I. M. Adv. Synth. Catal. 2016, 358, 2929.

(20) (a) Prodius, D.; Macaev, F.; Stingaci, E.; Pogrebnoi, V.; Mereacre, V. Novitchi, G.; Kostakis, G. E.; Anson, C. E.; Powell, A. K. Chem.
Commun. 2013, 49, 1915. (b) Fei, Z.; Zhao, D.; Geldbach, T. J.; Scopelliti, R.; Dyson, P. J. Chem. Eur. J. 2004, 10, 4886.

(21) (a) Bandyopadhyay, S.; Chandramouli, K.; Johnson, M. K. Biochem. Soc. Trans. 2008, 36, 1112. (b) Johnson, D. C.; Dean, D. R.; Smith, A. D.; Johnson, M. K. Annu. Rev. Biochem. 2005, 74, 247.

(22) (a) Bidart, C.; Jimenez, R.; Carlesi, C.; Flores, M.; Berg, A. Chem. Eng J. 2011, 175, 388. (b) Wasserscheid, P.; Keim, W. Angew. Chem. Int. Ed. 2000, 39, 3772.

(23) H. Xie, G. Li, F. Zhang, F. Xiao, G.-J. Deng, Green Chem. 2018, 20, 827 831.

(24) (a) Nguyen, T. B.; Retailleau, P. Green Chem. 2017, 19, 5371. (b) Poupaert, J.; Duarte, S.; Colacino, E.; Depreux, P.; McCurdy, C.; Lambert, D. Phosphorus Sulfur 2004, 179, 1959.

(25) Li, H.-Z.; Xue, W.-J.; Yin, G.-D.; Wu, A.-X. Tetrahedron Lett. 2015, 56, 5843.

(26) Nguyen, T. B.; Tran, M. Q.; Ermolenko, L.; Al-Mourabit, A. Org. Lett. 2014, 16, 310

(27) Guntreddi, T.; Vanjari, R.; Singh, K. N. Org. Lett. 2014, 16, 3624.

(28) Wu, J.-W.; Wu, Y.-D.; Dai, J.-J.; Xu, H.-J. Adv. Synth. Catal. 2014, 356, 2429. 